This manuscript is a non-peer reviewed preprint submitted to EarthArXiv, which has been submitted for peer-review to LANDSLIDES, the Journal of the International Consortium on Landslides.

Please note that the manuscript is under review and subsequent versions of this research article may have a slightly different content.

If accepted, the final version of the manuscript will be available via the "Peer-reviewed Publication DOI" link on this webpage. 


\title{
Created by the Monte Peron rock avalanche: Lago di Vedana (Dolomites, Italy) and its sediment record of landscape evolution after a mass wasting event
}

\author{
Bernd Zolitschka $^{1}$, Irene Sophie Polgar ${ }^{2}$, Hermann Behling ${ }^{2}$ \\ ${ }^{1}$ University of Bremen, Institute of Geography, Germany (corresponding author: zoli@uni-bremen.de) \\ ${ }^{2}$ University of Göttingen, Department of Palynology and Climate Dynamics, Germany
}

\section{ORCIDs}

Bernd Zolitschka: https://orcid.org/0000-0001-8256-0420

Irene S. Polgar: https://orcid.org/0000-0003-1116-4695

Hermann Behling: https://orcid.org/0000-0002-5843-8342

\begin{abstract}
The timing of the Monte Peron Landslide is revised to 2890 cal. BP based on a radiocarbon-dated sediment stratigraphy of Lago di Vedana. This age fosters the importance of hydroclimatic triggers in the light of accelerating global warming with a predicted increase of precipitation enhancing the regional predisposition to large landslides. Moreover, a layer enriched in allochthonous organic and minerogenic detritus dating to the same wet period is interpreted as response to a younger and yet unidentified mass wasting event in the catchment of Lago di Vedana.

Rock debris of the Monte Peron Landslide impounded the Cordevole River valley and created a landslidedammed lake. Around AD 1150, eutrophication of this lacustrine ecosystem started with intensified human occupation - a process that ended 150 years later, when the river was diverted back into its original bed. Most likely, this occurred due to artificial opening of the river dam. In consequence, Lago di Vedana was isolated from an open and minerogenic to an endorheic and carbonaceous lacustrine system. After a monastery was established nearby in AD 1457, a second eutrophication process was initiated due to intensified land use linked with deforestation. Only in the $18^{\text {th }}$ and $19^{\text {th }}$ century, deposition of organic matter decreased coinciding with climatic (Little Ice Age) and cultural changes. Conversational measures are the likely reasons for a trend towards less eutrophic conditions since AD 1950.
\end{abstract}

\section{Keywords}

Landslide, XRF scanning, geochemistry, soil erosion, cultural eutrophication, Late Holocene 


\section{Introduction}

Landslides are dangerous and extremely rapid natural hazards of mountain regions with the potential of causing hundreds of fatalities like after the Vajont Landslide in the Southern Alps in AD 1963 (Barla and Paronuzzi 2013; Rossato et al 2018). Within minutes mass wasting events drastically modify natural and human landscapes and significantly change their topography (Petley 2012). This risk grows with increasing population. As settlements and infrastructure develop into narrow alpine valleys they become exposed to landslide hazards. Therefore, understanding mechanisms, magnitudes and recurrence intervals of past landslides is mandatory to assess future risks. However, as risk management and risk reduction activities are forward-looking they need a past perspective for calibration (Strouth and McDougall 2021), an approach we tackle with this study.

The occurrence of landslides is generally controlled by predisposition factors such as vertical bedding of geological structures and proximity to major tectonic lineaments with higher risks for triggering earthquakes. In addition to seismicity, climate and humans are two other important triggers (Dapples et al 2002; Dikau and Schrott 1999). While climatic influence on mass wasting events is often modulated by centennial to millennial scaled variability in precipitation (Borgatti et al 2007) or by decreasing lateral pressure of melting glaciers leaving behind steep slopes with over-deepened valleys, seismic and human influences are accidental with the latter often linked to large-scale construction works (Barla and Paronuzzi 2013) or deforestation (Dapples et al 2002). On the one hand, increased water availability due to intense rainfall destabilizes slopes like during the destructive Val Pola rock avalanche, the most expensive natural hazard in Italy that occurred in AD 1987 with a volume of $0.04 \mathrm{~km}^{3}$ (Crosta et al 2004; Govi 1989). On the other hand, the largest mass wasting event of the Dolomites, the Vajont Landslide with $0.27 \mathrm{~km}^{3}$, occurred during filling of a reservoir when the rising water level caused slope destabilization (Barla and Paronuzzi 2013).

A large number of mass wasting events is considered for the ending Pleistocene, when rising temperatures during deglaciation were responsible for retreating glaciers and vanishing permafrost. However, due to the lack of organic matter from this time interval for dating with radiocarbon techniques, ages of these events were only tentatively estimated to fall between 20,000 and 14,000 cal. BP (Pellegrini et al 2006; Soldati et al 2004). Better chronologies exist for the Holocene, allowing a clustering of landslide events for the Dolomites in two periods: Early Holocene (10,700-8400 cal. BP) and first half of the Late Holocene (4000-2100 cal. BP). Both intervals are recognized as periods with intense precipitation (Borgatti and Soldati 2010).

Landslide-dammed lakes are frequent geomorphological features in the Dolomites persisting for centuries or millennia after causal mass wasting events (Borgatti et al 2007; Dai Pra and Giardini 2001; Pellegrini et al 2006; Rossato et al 2018). If backed up by a precise chronology and analyzed with a multiproxy approach including sedimentology, geochemistry, geomorphology and palynology, lacustrine sediment sequences from landslidedammed lakes preserve valuable stratigraphic records and provide detailed data of past environmental conditions (Soldati et al 2006). In this study, we investigate the lacustrine sediment record of Lago di Vedana, a relict lake of a once much larger landslide-dammed paleolake formed after the catastrophic rock avalanche at Monte Peron. With a volume of $0.17 \mathrm{~km}^{3}$ this is the second largest landslide of the Dolomites. Its age was initially estimated to Late Pleistocene (19,600-18,200 cal. BP) by Pellegrini et al (2006), but recently re-evaluated by cosmogenic exposure dating to the $2^{\text {nd }}$ century AD by (Rossato et al 2020). Time constraints for mass wasting events are rarely unequivocal. This is corroborated by a recent study of the Triolet Rock Avalanche in the Mont Blanc Massif (NW Italy), for which older bulk radiocarbon ages from the base of a peatbog, which developed on top of the rock debris, provided a wide range of ages not confirming the historical event in AD 1717. However, applying new AMS ${ }^{14} \mathrm{C}$ dating on woody fragments confirms the early $18^{\text {th }}$ century age of this peatbog Hajdas et al (2021).

We will unveil the regional environmental history of the post-landslide landscape, applying geochemical and sedimentological analyses to the radiocarbon-dated sediment archive from Lago di Vedana. Furthermore, human impact on vegetation history is reconstructed palynologically in a companion study for the last millennium (Polgar et al subm.). These studies shed new light on the timing of this huge mass wasting event and discusses 
natural climatic and human influences on the unique landscape it has created. Moreover, knowledge of the environmental history is important, as past landslides often were renewed if involved triggers pass certain thresholds (Govi 1989). No doubt, hydroclimatic triggers are gaining importance as global warming accelerates, a process also relevant for other regions of the Alps sensitive to changes in temperature and precipitation. Therefore, preparedness is required, as it is only a matter of time until another large landslide will occur with destructive consequences for the anthroposphere.

\section{Study Site}

Lago di Vedana is located in the Southern Italian Alps ca. $80 \mathrm{~km} \mathrm{~N}$ of the city of Venice and belongs to one of the tectonically most active regions of NE Italy. The study area is situated right on the Belluno Fault, a WSWENE oriented tectonic thrust (Pellegrini et al 2006) at the southern fringe of the Dolomites and in the Province of Belluno at $377 \mathrm{~m}$ asl $\left(46^{\circ} 09^{\prime} 36^{\prime \prime} \mathrm{N}, 12^{\circ} 06^{\prime} 22^{\prime \prime} \mathrm{E}\right.$; Fig. 1). Today this small lake with a water surface of 22,000 $\mathrm{m}^{2}$ (Andrich et al 2001) has a maximum water depth of $4.2 \mathrm{~m}$. Occasionally, the lake has a minor outflow via the Rio Ramon valley towards the Mis River in the W. However, Rio Ramon is an underfit stream in an oversized dry valley (Giordano 2015) and thus the lake basin is considered as endorheic despite its potential outflow. Lago di Vedana receives water only via precipitation and through groundwater inflow from the karst hydrological system of Piz de Vedana (1324 m asl) composed of Mesozoic limestones in the N, from the Cordevole River in the E flowing in a distance of $900 \mathrm{~m}$ at $387 \mathrm{~m}$ asl, i.e. $10 \mathrm{~m}$ above the modern lake level of Lago di Vedana, and from the widely spread Masiere di Vedana covering other directions.

The Masiere (Italian: stony ground) di Vedana is best described as a hummocky toma landscape with irregular topography and boulders of all sizes in a matrix of angular rock debris spotted with kettles and knobs (Rossato et al 2020) - a landscape characteristic for mass wasting deposits (cf., More and Wolkersdorfer 2019). These deposits are the result of the Monte Peron rock avalanche, which travelled a distance of $5.9 \mathrm{~km}$ and spread across the confluence plain of the Cordevole River and the Vallone Bellunense (Piave River valley) covering an area of $9 \mathrm{~km}^{2}$ with a thickness varying from 5 to $>30 \mathrm{~m}$ and an estimated volume of $0.17 \mathrm{~km}^{3}$ (Rossato et al 2020). On top of these rock-avalanche deposits, Lago di Vedana and todays peat bog Torbe developed as the successor of a landslide-dammed lake that formed immediately after this catastrophic event. After deposition of the Masiere di Vedana the Cordevole River valley was blocked with two major consequences: (1) the Cordevole River was diverted and changed its course by $90^{\circ}$ forming a river knee towards the Mis River valley in the W and (2) a landslide-dammed lake was formed between todays Cordevole River valley and Torbe peat bog (Rossato et al 2020). This paleolake was much larger than the modern Lago di Vedana causing deposition of lacustrine sediments: proximal gravels and distal silts. This lake existed until its dam was eroded. After the paleolake was drained towards the Mis River, the modern lake was created as a relict water body. However, the valley of Rio Ramon continued as drainage for the Cordevole River and became its alluvial plain (Giordano 2015). Sometime later, this changed when the dam in the Cordevole River valley breached at Ponte di Mas creating a gorge and thus allowing a return of the river water to its original stream channel leaving behind a dry Rio Ramon valley.

The surface water of Lago di Vedana has a pH of 8,8 and an electric conductivity of $202 \mathrm{mS} / \mathrm{cm}$ (Andrich et al 2001). Together with extensive growth of the rare European White Water Lily (Nymphaea alba) and a large siltation zone $\left(28,000 \mathrm{~m}^{2}\right)$ surrounding the lake (Andrich et al 2001), these limnological parameters point to recent cultural eutrophication, typical for many (small) water bodies since the middle of the $20^{\text {th }}$ century (cf., Jenny et al 2016). But there are reasons to assume that lacustrine conditions were affected by human impact already since the Middle Ages. To offer shelter for travelers, the Ospizio di San Marco di Vedana was founded in the early $12^{\text {th }}$ century and first documented in a pontifical bull from AD 1155 (Bacchetti and Selle 1985). This guesthouse (hospice) was located $1 \mathrm{~km} \mathrm{NE}$ of the lake in the village of San Gottardo. Two centuries later it was consigned to the Carthusian Order of Veneto in AD 1457 (Cariali 1998), which extended the service and started with the construction of Certosa di Vedana, a monastery located in $500 \mathrm{~m}$ distance NE of the lake. With a century-long interruption (AD 1768-1882), the monastery was active until AD 1977 (Bacchetti and Selle 1985). 


\section{Methods}

\section{Coring and Subsampling}

Two parallel sediment cores (LV18-A and LV18-B) from close by positions and at $4.2 \mathrm{~m}$ water depth were recovered in July 2018 from the center of Lago di Vedana $\left(46^{\circ} 09^{\prime} 36^{\prime \prime} \mathrm{N}, 12^{\circ} 06^{\prime} 22^{\prime \prime} \mathrm{E}, 377 \mathrm{~m}\right.$ asl) with a Livingstone piston corer (Nesje et al 1987). The maximum sediment depth reached $171 \mathrm{~cm}$. Deeper penetration was impossible due to hard rocks below. The cores (diameter: $50 \mathrm{~mm}$ ) were cut in two sections and transferred to the University of Göttingen, where they were stored cold and dark until split and described macroscopically. For microscopic sediment description (magnification: 100-400 x) at the University of Bremen, 68 smear slides were prepared following Rothwell (1989). Supporting core description, high-resolution color images are available from the line-scan camera mounted to the ITRAX X-ray fluorescence (XRF) core-scanner (Croudace et al 2019; Croudace et al 2006). The best preserved of the two parallel cores (LV18-B) was selected for analyses. Adjusted to the changing sediment composition at $137 \mathrm{~cm}$ depth, subsampling for sedimentology and geochemistry at the University of Bremen was carried out every $5 \mathrm{~cm}$ from $0-110 \mathrm{~cm}$, every $2 \mathrm{~cm}$ from 110-140 $\mathrm{cm}$ and every $1 \mathrm{~cm}$ from $140-171 \mathrm{~cm}$ providing a total of 68 samples.

\section{Dating}

Six AMS ${ }^{14} \mathrm{C}$ samples were dated at the Poznan Radiocarbon Laboratory in Poland (POZ). From the upper organic sediments two dates derive from terrestrial plant macro remains, while the minerogenic sediments below provide four ages on bulk organic matter. In addition to radiocarbon dates, the sediment/water interface (AD 2018) is used as a chronological tie point. The age-depth relationship for this sediment record was modelled using the R-package "rbacon" (Blaauw et al 2021). All radiocarbon dates were calibrated during age modelling by applying the Northern Hemisphere calibration curve IntCal20 (Reimer et al 2020). For a number of publications used in the discussion, radiocarbon dates are provided as uncalibrated ages. These ages were calibrated using OxCal 4.4 (Bronk Ramsey 2009) with the IntCal20 dataset (Reimer et al 2020) to improve comparisons with our data.

\section{Core Scanning}

Prior to applying non-destructive core scanning techniques, split core halves were cleaned and flattened. First, magnetic susceptibility (MS) was measured with $1 \mathrm{~cm}$ increments using a Bartington MS2E sensor mounted to a measuring bench (Nowaczyk 2001). High-resolution determination of geochemical composition was achieved with the ITRAX XRF core scanner from Cox Analytics (Croudace et al 2019; Croudace and Rothwell 2015). Measurements were carried out with the molybdenum (Mo) tube and constant settings of $30 \mathrm{kV}$ and $40 \mathrm{~mA}$, a step size of $2 \mathrm{~mm}$ and an exposure time of $5 \mathrm{~s}$. The output was processed with the software Q-spec (Cox Analytics) and results are expressed in counts (cts) and after division by exposure time in counts per second (cps).

Due to changing physical properties along the sediment record, the chemical composition obtained by XRF core scanning is non-linearly correlated to elemental concentrations (Croudace et al 2019; Tjallingii et al 2007). The reason are matrix effects related to variations in water content, organic matter content and/or grainsize.

Moreover, element intensities underlie the closed-sum effect, which inhibits multivariate statistical analyses (e.g., Martin-Puertas et al 2017). A solution for these limiting factors is available with the centered log-ratio (clr), which normalizes data and determines relative changes in element composition resembling their chemical composition (Tjallingii et al 2007; Weltje et al 2015; Weltje and Tjallingii 2008). Moreover, clr transformation is consistent with the statistical theory of compositional data analyses (Aitchison 1982; Weltje et al 2015) and calculates as:

clr of $\mathrm{I}_{\mathrm{ij}}=\ln \left(\mathrm{I}_{\mathrm{ij}} / \mathrm{gm}_{\mathrm{j}}\right)$, 
where $\mathrm{I}_{\mathrm{ij}}$ is the intensity (I) of the element i for measurement $\mathrm{j}$ and $\mathrm{gm}_{\mathrm{j}}$ is the geometric mean of all elements considered at measurement $\mathrm{j}$. In addition to elemental clr values, we calculate the log molybdenum incoherent/coherent scattering ratio ( $\mathrm{ln}$ inc/coh), which is regarded as a proxy for organic matter content of lacustrine sediments (Liu et al 2013; Woodward and Gadd 2019). This ratio of Compton scattering (inc) versus Rayleigh scattering (coh) depends on the presence of light elements (H, C, N, O). High amounts of these elements, such as analyzed for organic matter and water content, increase the Compton Effect and thus the value for $\mathrm{ln}$ inc/coh. Other possible matrix effects are negligible (Weltje and Tjallingii 2008; Woodward and Gadd 2019). All clr element data are low pass filtered applying a simple 7-point moving average.

\section{Physical Sediment Parameters}

To determine values for bulk dry density and water content, volumetric samples were dried at $105{ }^{\circ} \mathrm{C}$ in a drying cabinet and weighed before (wet) and after (dry). The difference between wet and dry sediment weights provides water content (in \%) and dry weight (in g). After division by sample volume dry bulk density (in $\mathrm{g} \mathrm{cm}^{-3}$ ) is calculated.

\section{Elemental Analyses}

Total carbon (TC), total nitrogen (TN) and total sulphur (TS) were measured with a CNS elemental analyzer (EuroEA, Eurovector). Prior to measurements, all 68 samples were freeze-dried, ground, homogenized and 5-20 mg were weighted for analysis in tin crucibles. During measurements, the elemental analyzer combusts the crucibles with the sample at a temperature of $1800^{\circ} \mathrm{C}$. All organic matter is oxidized and the resulting gases $\left(\mathrm{CO}_{2}, \mathrm{NO}_{2}, \mathrm{SO}_{2}\right)$ are detected by chromatography (Meyers and Teranes 2001). As TC includes organic as well as inorganic carbon, a second step is necessary to distinguish between total organic carbon (TOC) and total inorganic carbon (TIC). All samples were treated first with $3 \%$ and then with $20 \% \mathrm{HCl}$ at $80{ }^{\circ} \mathrm{C}$ to remove carbonates prior to measurement of TOC with the same CNS analyzer. Total inorganic carbon (TIC) was then calculated as the difference between TC and TOC. Furthermore, and to distinguish autochthonous from allochthonous sources of organic matter, $\mathrm{C} / \mathrm{N}$ ratios were calculated (Meyers and Teranes 2001).

Biogenic silica (BSi) was analyzed for 48 samples following the leaching method of Müller and Schneider (1993). We extracted $\mathrm{BSi}$ with $1 \mathrm{M} \mathrm{NaOH}$ at $85^{\circ} \mathrm{C}$. The solution was cycled by a continuous-flow system into an auto analyzer, where dissolved silicon was detected by spectrophotometry.

\section{Grainsize}

Prior to grainsize analysis of 68 samples, organic matter was removed with $\mathrm{H}_{2} \mathrm{O}_{2}(30 \%)$, carbonates with $\mathrm{HCl}$ $(10 \%)$ and diatoms with $\mathrm{NaOH}(2 \mathrm{~mol} / \mathrm{l})$. For dispersion, $20 \mathrm{ml}$ of Calgon $\left[\left(\mathrm{NaPO}_{3}\right) \mathrm{n}\right]$ was added and agitated overnight. On the next day, analyses were performed with a laser diffraction analyzer (Beckman Coulter LS 200) after ultrasonic treatment for $30 \mathrm{~s}$. Each sample was measured at least four times for $60 \mathrm{~s}$ until a stable distribution was reached. Thereafter, the arithmetic mean was calculated for the best three sample runs. Grainsize distributions and all statistical grainsize parameters were calculated from the output of the LS200 as geometric graphical measures according to Folk and Ward (1957) with the MS Excel-based macro Gradistat, Version 8.0 (Blott and Pye 2001).

\section{Results}

\section{Lithological Description}

Based on macroscopic and microscopic sediment characterization and supported by physical and chemical parameters, the record is subdivided into five lithozones (LZ): LZ A to LZ E (Figs. 2, 3).

Basal LZ A (171-140 cm) consists of yellowish gray (2.5Y 5/1) to dark grayish yellow (2.5Y 5/2) mud with a 5 mm-thin black (5Y 2/1) layer of sandy silt at $164 \mathrm{~cm}$. Sediments are characterized as minerogenic according to their high values for physical properties, except for water content which is lowest. All parameters decrease 
(water content increases) towards the top of LZ A. The mean grainsize is $<6 \mu \mathrm{m}$ with one exception: the thin black layer has a mean of $14 \mu \mathrm{m}$ (Fig. 2). In terms of chemical composition, TOC and TIC have relatively stable low values of $\sim 2$ and $\sim 4 \%$, respectively, and increase towards the top (Fig. 3). TS and BSi behave differently: both are low at the base but increase to maxima at $142 \mathrm{~cm}$ (Fig. 3). The $\mathrm{C} / \mathrm{N}$ ratio marks the black layer with a prominent increase to 11 and lower values of 8 below and above. Further on, $\mathrm{C} / \mathrm{N}$ ratios drop to a low $(<6)$ at $148 \mathrm{~cm}$. Thereupon, $\mathrm{C} / \mathrm{N}$ ratios increase again. At the transition to $\mathrm{LZ} \mathrm{B}$ charcoal is detected microscopically.

Grayish olive (5Y 5/2) to grayish yellow (2.5Y 7/2) faintly laminated, diatomaceous and carbonaceous mud describes LZ B (140-123 cm). Sediments shift from minerogenic to organic as indicated by increasing TOC and constantly high $\mathrm{BSi}$. Although $\mathrm{BSi}$ becomes absent before $\mathrm{LZ} \mathrm{B}$ ends, TOC as well as $\mathrm{C} / \mathrm{N}$ ratios continue to rise, while TIC reaches an all-time maximum at $133 \mathrm{~cm}(9.9 \%)$. TS displays a different behavior and decreases to $<0.1 \%$ throughout LZ B (Fig. 3). With regard to physical parameters, magnetic susceptibility reaches low values already at the onset of LZ B, while dry bulk density (and water content) still decrease (increase) during LZ B until they reach lowest (highest) values at its top. Mean grainsize has a different signature and with $17.5 \mu \mathrm{m}$ marks an all-time maximum at $131 \mathrm{~cm}$ depth (Fig. 2).

The sediment sequence continues with dark olive black (5Y 3/2) organic mud for LZ C (123-113 cm). Mean grainsize is the only physical parameter showing a minor increase after a small drop at the onset of LZ C (Fig. 2). However, high values are recorded for most chemical parameters: TOC and TS have their second highest maxima at $9 \%$ and $0.3 \%$, respectively. $\mathrm{C} / \mathrm{N}$ ratios approach the highest value of the record (11). TIC drops to lower values while diatoms remain absent (Fig. 3). Microscopically, LZ C is characterized by a lack of diatoms but presence of terrestrial plant macrofossils as well as charcoal fragments. Moreover, pyrite becomes ubiquitous often forming microscopically detectable framboids. Larger silt grains were observed as well.

Grayish yellow (2.5Y 6/2) to grayish olive (5Y 6/2) carbonaceous organic mud describes LZ D (113-45 cm). All physical parameters as well as TIC (after an initial increase from 6 to $8 \%$ ) and TS display no variability (Figs. 2, 3). Diatoms remain absent and TOC first decreases from initially 8 to $5 \%$ at $75 \mathrm{~cm}$ depth and then increases again to $7 \%$ at the top of $\mathrm{LZ} \mathrm{D}$, while $\mathrm{C} / \mathrm{N}$ ratios decrease from 11 to 8 at $85 \mathrm{~cm}$ depth and thereafter remain constant towards the top. Microscopic observations document no more pyrite and charcoal as well as a decrease in terrestrial plant remains.

Topmost LZ E $(45-0 \mathrm{~cm})$ is characterized by gray $(10 \mathrm{Y} 6 / 1)$ to dark grayish yellow $(2.5 \mathrm{Y} 5 / 2)$ gas-rich organic mud with TOC increasing to a maximum of $12 \%$ at $10 \mathrm{~cm}$. C/N ratios increase to a maximum of 9 at $34 \mathrm{~cm}$. At $10 \mathrm{~cm}$ both values start to decline. At the same depth BSi reappears and increases towards $1.1 \%$ at the sediment surface (Fig. 3).

\section{Stratigraphy of Selected Elements}

High-resolution XRF core-scanning data support the lithological description. Due to their high spatial resolution of $2 \mathrm{~mm}$, these records are more detailed and provide additional compositional sediment information. The XRF scanner detected 27 elements with mean counts varying from $12(\mathrm{Mg})$ to 16,663 (Ca) as well as coherent (coh) and incoherent (inc) radiation. However, the majority of elements has low signal-to-noise ratios and was excluded from further discussion if XRF count rates are $<35 \mathrm{cps}$. With this reasoned decision, seven elements $(\mathrm{K}, \mathrm{Ca}, \mathrm{Ti}, \mathrm{Mn}, \mathrm{Fe}, \mathrm{Rb}, \mathrm{Sr})$ as well as the inc/coh ratio remain for further interpretation (Fig. 4). These elements fall into three categories: (1) K, Ti and Fe are related to siliciclastic minerals and dominate LZ A. (2) Ca and $\mathrm{Sr}$ are bound to carbonates, which are absent during LZ A but provide the dominating sediment component for $\mathrm{LZ}$ B. Here, they cause a dilution of siliciclastic elements that respond with minima. Carbonates are also present during LZs D and E, although with lower values and distinctly reduced for LZ C. (3) The $\ln$ (inc/coh) ratio is a well-known proxy for organic matter (Woodward and Gadd 2019), correlates with TOC $(r=0.96)$ and provides a high-resolution record of organic matter for Lago di Vedana. This ratio displays lowest values for minerogenic LZ A, which increase throughout LZ B and reach a first maximum in LZ C. These high values continue into LZ $\mathrm{D}$, then decrease to a minimum between $80-60 \mathrm{~cm}$ and rise again into LZ E and towards the top of the record (Fig. 4). 


\section{Grainsize Statistics and Sediment Dynamics}

Our data document a mean grainsize of $\sim 6 \mu \mathrm{m}$ for most of the record. However, there are three distinctly different sections (Figs. 2, A1). The first event starts with the thin black layer at $164 \mathrm{~cm}$ where coarse silt (cSi) and fine sand (fS) increase confirming the macroscopic sediment description. The second event starts at $150 \mathrm{~cm}$, when first cSi increases towards a maximum at $140 \mathrm{~cm}$. While the cSi fraction decreases, very cSi and fS start to rise from 132-124 cm. After this maximum, a distinct drop of these fractions is followed by a third but minor maximum at $120 \mathrm{~cm}$ (LZ C) and continues to the base of LZ D until $100 \mathrm{~cm}$.

\section{Age-Depth Model}

All radiocarbon dates are tabled in Fig. 5. Ages from organic deposits are in stratigraphic order, while those from minerogenic LZ A range from 6730 to 2920 cal. BP and display reversals (Fig. 5). Only the youngest age is considered as reliable and the three older ages as being obtained from reworked organic matter. Thus, we accept a basal age of $2920 \mathrm{cal}$. BP for the age-depth model resulting in an almost exponential trend in sedimentation rates (Fig. 5). Lowest mean sedimentation rates of $0.15 \mathrm{~mm} / \mathrm{a}$ occur for minerogenic LZ A. They increase to 0.72 $\mathrm{mm} / \mathrm{a}$ for LZ B and to $1.54 \mathrm{~mm} / \mathrm{a}$ for LZs C and D. Highest mean sedimentation rates of $10 \mathrm{~mm} / \mathrm{a}$ are obtained for LZ E.

\section{Interpretation}

Based on lithology as well as on physical and chemical data, sedimentation at Lago di Vedana is divided in two different modes (Fig. 2). Involved depositional processes include (1) Late Holocene flooding activities of Cordevole River responsible for minerogenic deposits in a landslide-dammed lake or on a flood plain and (2) increasingly organic lacustrine deposits since Medieval Times in an endorheic lake.

\section{Late Holocene minerogenic sediments}

From 2900 to 650 cal. BP (950 BC - AD 1300) the record is characterized by minerogenic sediments (LZ A). Organic contributions are minor (TOC: $\leq 2 \%$ ), also elements related to carbonaceous components ( $\mathrm{Ca}, \mathrm{Sr}$ ) are subordinated, while siliciclastic sediment components $(\mathrm{K}, \mathrm{Ti}, \mathrm{Fe})$ as well as magnetic susceptibility and dry bulk density are at their maxima (Figs. 2-4, 6). The overall sediment matrix is composed of homogenous medium silt without any bedding structures except for one distinct $5 \mathrm{~mm}$-thick layer at $164 \mathrm{~cm}$ depth (see below). This minerogenic character is modified towards the top of LZ A when diatom productivity increases accompanied by a distinct rise in TS (Fig. 3) together with a slight increase in grainsize, particularly of the cSi fraction (Fig. S1). Simultaneously, magnetic susceptibility decreases although other parameters of siliciclastic deposits (K, Ti, dry bulk density) remain at high levels (Figs. 2, 4, 6).

The distinct black layer at $164 \mathrm{~cm}$ depth is remarkable because it contains $54 \%$ of cSi and fS (Figs. 2, A1) and coincides with a slight increase in TOC and a distinct maximum of the $\mathrm{C} / \mathrm{N}$ ratio. Moreover, this layer is preceded by a drop in magnetic susceptibility together with a rise of $\mathrm{Fe} / \mathrm{Mn}$ ratios and also succeeded by a rise in diatoms as indicated by BSi (Fig. 6). The overall formation of minerogenic LZ A is attributed to three different processes.

\section{Fluvial activity responsible for minerogenic deposition}

Today, Lago di Vedana is located at the northern fringe and on top of landslide deposits (Masiere di Vedana) created by the Monte Peron rock avalanche. This event blocked not only the valley of Cordevole River near Ponte di Mas to the S, but also its alternative path through Rio Ramon towards the W. Both valleys were obstructed by rock debris establishing a landslide-dammed paleolake. The siliciclastic sediments that were deposited with dominance of K, Ti and Fe (Figs. 4, 6) are not from the modern catchment area of Lago di Vedana, which is dominated by carbonaceous rocks of the southern Dolomites. Instead, these sediment components originate from the large catchment area of Cordevole River also comprising volcanic and metamorphic rocks (Giordano 2015). Basal minerogenic sediments are thus explained as distal deposition in a landslide-dammed lake. However, this lake needs to have been a flow-through lake from the beginning to justify 
the lack of very fine grains as well as the lack of any laminations in the sediment record (cf. Figs. 88, 95, 96 of Giordano, 2015). Another explanation assumes that the landslide-dammed lake existed only for a few years or decades and then lacustrine deposition was replaced by distal fluvial deposition on the former Cordevole River floodplain. This option is even more realistic because Alpine rivers transport large amounts of sediment and thus any lake that develops in the course of such a river would be silted-up rapidly due to high sedimentation rates, like they have been determined with $6.5 \mathrm{~mm} / \mathrm{a}$ (range: 5.2-10.4 mm/a) for the Early Holocene Pescosta Paleolake (Borgatti et al 2007) and with $15 \mathrm{~mm} / \mathrm{a}$ for the Holocene sediment record from Lago di Santa Croce (Pellegrini et al 2006). The latter lake was dammed by the Fodalto Landslide in the Piave River valley and is still existing today because the Piave River was permanently diverted after the mass wasting event and only minor tributaries contributed sediment since then. The observed sedimentation rates of $0.15 \mathrm{~mm} / \mathrm{a}$ at Lago di Vedana are too low for deposition in a landslide-dammed lake over a time period of $>2000$ years. Thus, occasional distal river floods as sources of these sediments are favored. Finally, and starting around AD 1300, minerogenic sediments were replaced by organic deposition. This distinct change is explained by a sudden change in sediment provenience. The most likely process that caused this development is opening of the dam at Ponte di Mas. From then onwards, Cordevole River returned to its traditional course and the basin of Lago di Vedana became isolated and endorheic.

\section{Runoff event interrupts the fine-grained clastic deposition}

Only one distinct layer within LZ A occurs at $164 \mathrm{~cm}$ and is related to a marked color change to black, an increase in grainsize (Figs. 2, A1) as well as slightly higher TOC values associated with a distinct rise in $\mathrm{C} / \mathrm{N}$ ratios (Figs. 3, 6). These parameters are supported by microscopic smear-slide analyses that indicate allochthonous deposition of $\mathrm{cSi}$ and fS particles as well as mm-sized wood fragments. Below this layer, values for magnetic susceptibility decrease (Fig. 2) while Fe/Mn ratios increase (Figs. 4, 6). Together, this reflects increased anoxic conditions, an assumption corroborated by the black color of the layer indicating iron sulfides. However, this short oxygen-free period is rather weak as hardly any increase of TS is documented (Fig. 6). A few centuries after this event biogenic silica rises (Figs. 2, 6) indicating a release of nutrients into the lake before returning to lower values again. The origin of this event has to be related to a flood event created in the catchment area of the Cordevole River. Such high discharge events are either linked to rainstorms or to a sudden release of a large amount of river water, e.g. due to a breaking dam after an upstream river obstruction. As intense precipitation events should have been recorded more frequently than just once in $>2000$ years, we suggest that a landslide in the Cordevole River valley or its tributaries occurred prior to $600 \mathrm{BC}$ and its erosional destruction caused the exceptional flood layer recorded by the sediments of Lago di Vedana.

\section{Cultural eutrophication increased diatom productivity}

Starting around AD 1000 and more distinctly since AD 1150, diatom deposition increased. This process is a response to eutrophication causing anoxia that formed pyrite as indicated by a maximum in TS and a rise of the $\mathrm{Fe} / \mathrm{Mn}$ ratio (Fig. 6). Anoxic conditions are also the reason for decreasing magnetic susceptibility values prior to the $\mathrm{K}$ and Ti decrease (Fig. 2), as magnetic carriers such as Fe-bearing minerals decay under anoxic conditions and non-magnetic iron sulfite (pyrite) crystallizes. At this stage, the amount of organic matter in the sediment increases only marginally (Fig. 6), most likely because productivity of non-siliceous algae in the epilimnion was still relatively low. Finally, the slight increase in grainsize transferred to the lake (Fig. S1) is interpreted as a reaction to destabilizing soils around Lago di Vedana, which coincides with the start of eutrophication. This process of increasing eutrophication combined with soil erosion is related to intensified human activities in the catchment area during medieval times. Historic data confirm the existence of the Ospizio di San Marco di Vedana already in AD 1155. In a distance of $1 \mathrm{~km}$ from the lake, this guesthouse sustained travelers with housing and food. Thus, agricultural activities such as livestock farming as well as deforestation with initial agricultural land-use practices were necessary in its vicinity and most likely responsible for soil erosion and initial eutrophication of Lago di Vedana.

\section{Organic sediments since the Late Middle Ages}

Organic deposits started around 650 cal. BP (AD 1300) and continue towards the present day. Sediments are the result of increased lacustrine productivity and subdivided into four lithozones (LZs B-E). 
In terms of organic deposition LZ B is a transitional period. On the one hand, dry bulk density drops to lowest values that continue towards the core top (Fig. 2). On the other hand, siliciclastic elements (K, Ti, Fe) reach their all-time minimum in the middle of LZ B and then start to increase, although to a much lower level compared to LZ A. While dry bulk density is decreasing, a rise in TOC is observed. At the same time, BSi remains at its high level (Fig. 3). Although these parameters indicate an overall increase in lacustrine productivity, TS drops from its record-high at the top of LZ A to very low values and indicates that anoxia have disappeared, which is also supported by low $\mathrm{Fe} / \mathrm{Mn}$ ratios (Fig. 6). In response to high lacustrine productivity, indicators of carbonaceous sediment components (TIC, $\mathrm{Ca}, \mathrm{Sr}$ ) are predominating LZ B, a process also documented by a change to a pale sediment color (Figs. 2-4). We assume that this large increase especially of $\mathrm{Ca}$ is responsible for the distinct drop in $\mathrm{K}, \mathrm{Ti}$ and $\mathrm{Fe}$ at the same time. Although the clr transformation of elemental data should exclude dilution effects, it cannot be ruled out for this case. Finally, allochthonous sediment components, grainsize and $\mathrm{C} / \mathrm{N}$ ratios display a slightly different behavior. $\mathrm{C} / \mathrm{N}$ ratios are rising in a comparable manner like TOC and inc/coh ratios, while grainsize is reaching an all-time maximum for $\mathrm{fS}$ in the middle of LZ B and drops thereafter.

A distinct shift in most geochemical parameters characterizes LZ C. Minerogenic proxies (magnetic susceptibility, dry bulk density) stay low for the remaining part of the record (Fig. 2). An increase in siliciclastic elements $(\mathrm{K}, \mathrm{Ti}, \mathrm{Fe})$ is attributed to decreasing dilution by $\mathrm{Ca}$ (Fig. 4). Parameters indicating organic matter (TOC, inc/coh ratio) continue to rise and reach a first maximum in LZ C, while diatoms disappear (Figs. 3, 4). However, anoxic conditions develop again as indicated by TS and Fe/Mn ratios (Fig. 6). Mean grainsize increases after lower values at the onset of LZ C to another maximum in fS (Fig. S1), which, however, does not reach the earlier maxima. Simultaneously, $\mathrm{C} / \mathrm{N}$ ratios arrive at very high values.

A distinctly paler color compared to LZ C is indicative for $\mathrm{LZ} \mathrm{D}$, which accordingly shows higher $\mathrm{Ca}$ and TIC values (Figs. 3, 4, 6). This development goes along with high organic matter at the base, which first decreases and then increases again towards the top of LZ D (Figs. 3, 4, 6). Anoxia seem to become less prominent, as TS and $\mathrm{Fe} / \mathrm{Mn}$ ratios drop to lower values, which stay constant to the core top like most other parameters as well (Fig. 6).

The topmost LZ E is of darker color with more organic matter, higher $\mathrm{C} / \mathrm{N}$ ratios and slightly less siliciclastic elements $(\mathrm{K}, \mathrm{Ti}, \mathrm{Fe})$. The most prominent feature of this lithozone is the rise of diatoms (BSi) for uppermost samples (Figs. 3, 6).

\section{From an open clastic to a closed carbonaceous lake basin}

The development from a siliciclastic depositional system to a lake dominated by carbonates occurs at the onset of LZ B around AD 1300 as consequence of suspended influence of the Cordevole River. Since then, the lake received no more river inflow. The reason for this distinct hydrological change was the destruction of the dam near Ponte di Mas, until then obstructing the original course of the Cordevole River. A reason for the dam breakage could have been natural erosion. However, the pressure of runoff on the dam was low because the river water was using an alternative path through the Rio Ramon valley. Thus, artificial opening of the dam is more likely. Especially, as medieval farmers and monks are well-known for increased activities related to water management in the vicinity of their villages and monasteries to create ponds for fishery, reduce flooding risks and/or extend their farm land by lowering the groundwater table (e.g., Schreg 2020).

Another consequence of disappearing river influence aside from the lack of minerogenic matter deposition was the lowering of the groundwater table. Thus, discharge through the karst hydrological system from surrounding carbonate rocks was increased. Moreover, subaquatic karstic wells introduced dissolved $\mathrm{Ca}$ into the lake system. Based on the elevated trophic state, lacustrine productivity removed $\mathrm{CO}_{2}$ from the water and caused the precipitation of calcite in the lake. This occurred mostly as incrustations of water plants, which were abundant in this relatively shallow lake. Idiomorphic calcite crystals precipitated from the water column were detected by smear-slide analysis only occasionally. At the same time, the constant inflow of groundwater increased the availability of oxygen in the lake and therefore anoxia disappeared. 


\section{Human activities and lake eutrophication}

Since the foundation of the Ospizio di San Marco di Vedana in the early $12^{\text {th }}$ century monks were present and caused a land-use change with accompanying eutrophication of Lago di Vedana documented by an increase in diatoms (Fig. 6) as well as by soil erosion evidenced by increasing grainsize (Fig. S1). Thus, eutrophication started already $\sim 150$ years before fluvial sedimentation ceased. About $\sim 150$ years later, Certosa di Vedana was founded. It is possible that monks changed the course of the river already 150 years prior to building the monastery in the $15^{\text {th }}$ century. At about the same time, diatoms disappear with BSi percentages tending against zero, while organic matter is still increasing. At this point a threshold level towards a higher trophic state seems to have been crossed where green algae outcompeted diatoms.

\section{Oligotrophication due to environmental protection}

Since the 1950ies organic matter content (TOC, inc/coh ratio) increased to an all-time maximum around AD 1970 after which a slight decrease occurred simultaneously with lower Fe/Mn ratios, less allochthonous minerogenic matter and at the same time more allochthonous organic matter, i.e. higher $\mathrm{C} / \mathrm{N}$ ratios. Finally, diatoms reappeared for the last few decades of the record. Altogether, this is a typical development for Central European lakes, which experienced a marked increase in cultural eutrophication after World War II (Jenny et al 2016). However, since the 1970s emplacement of the European Water Legislation caused a decrease in domestic phosphorous pollution resulting in lowering of trophic conditions (oligotrophication) of rivers and lakes. Furthermore, in AD 1977 activities of the monks at Certosa di Vedana ended (Bacchetti and Selle 1985) and measures of natural protection were installed around the lake, such as the foundation of the Parco Nazionale delle Dolomiti Bellunesi in AD 1990 (Andrich et al 2001) and the Natura 2000 protection area "Dolomiti Feltrine e Bellunesi" including "Lago e Torbe di Vedana" created in AD 2003 (https://eunis.eea.europa.eu/sites/IT3230083). Altogether, these developments passed a threshold in lacustrine productivity to foster diatoms instead of non-siliceous green algae. Additionally, reforestation in the catchment area on the one hand reduced the already low siliciclastic component even further and on the other hand caused an increase of allochthonous organic matter indicated by higher $\mathrm{C} / \mathrm{N}$ ratios (Fig. 6).

\section{Discussion}

\section{Monte Peron Landslide - Chronological Considerations}

Evidences in support of the deglacial age for the Masiere di Vedana are not convincing. There exist only geomorphological constraints related to the extensive distribution of debris from the rock avalanche, which are interpreted as successive mass movements deposited onto the retreating Cordevole Glacier with subsequent glacial transport of rock debris down the valley. Linking this landslide to glacial unloading provides a time window of ca. 19,600-18,200 cal. BP (Giordano 2015; Pellegrini et al 2006). However, there is no independent dating from outcrops of the Masiere di Vedana or any other observations in support of this timing.

A recent interpretation of the Masiere di Vedana suggests only one mass wasting event. Additionally, a chronology was established combining archaeological findings with ${ }^{36} \mathrm{Cl}$ exposure dating. The obtained age of $1.9 \pm 0.45 \mathrm{ka}$, i.e. between $340 \mathrm{BC}$ and $\mathrm{AD} 560$, represents the historical Roman Empire of the $2^{\text {nd }}$ century $\mathrm{AD}$ (Rossato et al 2020). This age is the mean of six exposure ages from boulders across the Masiere di Vedana ranging from $1.45 \pm 0.12$ to $2.39 \pm 0.38 \mathrm{ka}$ and excludes one outlier of $3.62 \pm 0.41 \mathrm{ka}$. As this statistical mean of six out of seven age estimations has a wide temporal spread of $0.94 \mathrm{ka}, 2.17 \mathrm{ka}$ including the outlier, it cannot be excluded that boulders of different mass wasting events have been dated or that other dating issues are involved. Moreover, archaeological evidences are weak. Rossato et al (2020, p. 2166) argue that the region "was largely and uniformly inhabited by incolae for agricultural aims" but no Roman findings were excavated from the Masiere di Vedana. Evidences for Neolithic and Roman sites only exist from its surroundings. The authors conclude that the landslide could not have occurred after Roman Times because then Roman archaeological remains must have been buried underneath the Masiere di Vedana and should have been excavated by numerous modern earthworks. This is probably true, but how realistic is the assumption that the landslide occurred during 
Roman Times as suggested by Rossato et al (2020)? This calls for a more sophisticated historical investigation: If this huge mass wasting event happened during a period with regional Roman activities, and this is what the exposure date of the $2^{\text {nd }}$ century $\mathrm{AD}$ implies, it would be amazing if such an event would not have been documented by the Romans. Furthermore, Romans might have avoided establishing buildings in a landscape that appears frightening, dangerous and not at all hospitable.

The age of $2900 \mathrm{cal}$. BP we obtained for the Masiere di Vedana is, like the exposure date, in strong contrast to a deglacial age and thus both approaches confirm a much younger timing for this landslide. Our radiocarbon-dated stratigraphical record, however, does not allow a younger age for this event like it is provided by exposure dating. As Lago di Vedana developed on top of the Masiere di Vedana, it needs to be younger than the event itself. Moreover, the dated base of the record is above hard rocks not penetrable for lake coring devices. Thus, we consider that the entire lacustrine record was recovered and the basal age is regarded as a minimum age. In consequence, our Late Holocene age needs other disposition factors than glacial unloading or earthquakes to be considered for future risk assessments.

\section{Evidences for a landslide at $\sim 600 \mathrm{BC}$}

The sedimentological event recorded at $164 \mathrm{~cm}$ and dated to $2600 \mathrm{cal}$. BP is interpreted as the response to a flooding event caused by erosion and catastrophic outflow of a landslide-dammed lake in the catchment area of the Cordevole River. Comparable event layers have been reported from Pescosta Paleolake (Corvara in Badia, Dolomites), which existed for ca. 3000 years during the Early Holocene (Borgatti et al 2007). Here, eight layers enriched in allochthonous organic debris are deposited as up to $18 \mathrm{~cm}$ thick fining upward layers in a Si to fS matrix. At Pescosta, these layers have also been studied for taphonomic properties of pollen and terrestrial plant macro remains, which reveal distinct perturbations compared to the general pollen record (Borgatti et al 2007). Moreover, and based on the elaborated radiocarbon chronology for the Pescosta Paleolake, these event layers have been related to gravitational processes in the catchment area.

We thus conclude that the organic debris layer in the sediment record from Lago di Vedana most likely is also related to a gravitational event in the catchment area. The relation to a discrete mass wasting event still awaits to be discovered. To achieve this goal, more high-resolution and multiproxy investigations are needed from sediment records of landslide-dammed lakes in the Alps. Establishing a more comprehensive landslide database also seems mandatory to increase the awareness for destructive mass wasting events in the light of global climate change.

\section{Landslide-Dammed Paleolakes in the Dolomites}

Large mass wasting events and related landslide-dammed lakes are common features in tectonically active regions like the Dolomites. In the catchment area of the Cordevole River two events have been published. (1) Around 6650 cal. BP the Cordevole River was dammed by a landslide, which formed Lago di Agordo (Dai Pra and Giardini 2001). This paleolake is located $18 \mathrm{~km}$ upstream from Ponte di Mas. A $25.4 \mathrm{~m}$ thick sediment record was recovered with the upper $5 \mathrm{~m}$ consisting of alluvial fan deposits while sediments below are composed of silts and sandy silts. Ca. 500 years after its formation this lake was silted up completely and developed into an alluvial plain (Dai Pra and Giardini 2001). (2) A historic landslide in the Cordevole River valley occurred on January 11 in AD $1771 \mathrm{ca} .33 \mathrm{~km}$ upstream from Ponte di Mas after a period of prolonged and heavy rainfall. The valley was blocked by $0.01 \mathrm{~km}^{3}$ of rock debris damming Lago di Alleghe (Rossato et al 2018). This lake was artificially stabilized and still exists today without information about its sediments.

For two other landslide-dammed lakes in the nearby Piave River valley an age between the Last Glacial Maximum and the Lateglacial, i.e. after the Piave Glacier had withdrawn, is postulated (Pellegrini et al 2006). In the case of the Fadalto Landslide with a volume of $0.135 \mathrm{~km}^{3}$, the landslide-dammed Lago di Santa Croce still exists today. The reason for not having silted up until today is the diversion of the Piave River, which originally drained through the Lapisina Valley and after the Fadalto Landslide changed to its current course in the Vallone Bellunense. Thus, sediment transfer into the lake basin was reduced considerably. A total of $163 \mathrm{~m}$ of lacustrine sediments were recovered from this site. Further downstream, the Marziai Landslide with a volume of $0.05 \mathrm{~km}^{3}$ 
obstructed the Piave River and caused deposition of lacustrine sediments with a maximum thickness of $110 \mathrm{~m}$. After silting up, fluvial sediments were deposited on top (Pellegrini et al 2006).

Further N in the Dolomites, the Pescosta Palaeolake formed due to a landslide near Corvara in Badia at 10,200 cal. BP (Borgatti et al 2007). The sediment record has a $10 \mathrm{~m}$ thick base of coarse gravel, followed by lacustrine silts and sands with a thickness of $17.3 \mathrm{~m}$ that extend for about 3000 years and are covered by $1.5 \mathrm{~m}$ of alluvial fan deposits. The fine-grained lake sediments are interrupted by several organic rich layers that were correlated to known mass wasting events in the catchment area (Borgatti et al 2007).

The Monte Peron Landslide was the largest of all described events with a volume of $0.17 \mathrm{~km}^{3}$ (Rossato et al 2018). Six cores with fine-grained lacustrine sediments (silt, sand) have been recovered from flat areas between toma hills of the Masiere di Vedana and are interpreted as deposits of a landslide-dammed lake (Rossato et al 2020). Assuming that erosion does not play a significant role, this is another evidence for the relatively young age of the Masiere di Vedana.

\section{Human Influence on Sedimentation}

Processes in lakes are generally controlled by climatic factors and, if humans are present in the catchment area, modified by anthropogenic influences. For the Dolomites, settlements have been reported since the Bronze Age (Pignatti and Pignatti 2014) and for the catchment area of Lago di Vedana human occupation is documented since the establishment of the Ospizio di San Marco di Vedana in the early $12^{\text {th }}$ century (Bacchetti and Selle 1985). This influence increased with the construction of the Certosa di Vedana after AD 1456. A valuable proxy verifying human activities for the sediment record from Lago di Vedana is provided by palynology (Polgar et al subm.). Here, we refer to Anthropogenic Pollen Indicators (API) according to Behre (1981) and Mercuri et al (2013) and to non-arboreal pollen (NAP) (Fig. 6). Unfortunately, pollen concentration for minerogenic LZ A is too low and the pollen record starts with the onset of organic deposition since AD 1300 (Polgar et al subm.). Therefore, first impacts of colonization in the $12^{\text {th }}$ century are not documented by the pollen record.

The foundation of the Certosa is prominently recorded by a rapid increase in API, which continues until AD 1670 and then declines towards AD 1800 (Fig. 6), a development that favorably agrees with the cessation of monastic work in AD 1768 (Polgar et al subm.). More than one century later the monastery was re-established in $\mathrm{AD}$ 1882. In the intervening period it was used as a farm building. This administrative change had consequences on land-use intensity, which diminished according to API between AD 1760 and 1840 - a period when also organic matter contents of lacustrine sediments indicates a distinct minimum (Fig. 6). Finally, the Certosa was closed in AD 1977 and API dropped to a record minimum. The sediment record from Lago di Vedana documents that human activities coincide with significant influences on the catchment area, like e.g. land-use changes recorded by decreasing arboreal pollen content (Polgar et al subm.), and is also accompanied by marked changes in the lacustrine system, such as eutrophication and development of anoxia in the water body (Fig. 6).

\section{Climatic Influence on Sedimentation}

The sediment record from Lago di Vedana does not provide parameters directly attributable to climate variability. Variations in the record are linked to a landslide-induced flood layer in the minerogenic section (LZ A) and to organic sections (LZs B-E) dominated by human impact. However, there are some indications of indirect climatic influence.

Although an assessment linking modern landslide activity to climate change provides only ambiguous evidence (Huggel et al 2012), the influence of climate on the occurrence of mass wasting events during the Holocene has been documented by many investigations. Not only in Europe but worldwide, c.f. summary with examples in Borgatti et al (2007), landslides are considered as indicators of climatic change with heavy rainfall being their prominent trigger (Soldati et al 2004). This is especially recognized for the time window from 5400-2300 cal. BP when colder temperatures were recognized for Central Europe (Haas et al 1998) and particularly for the Alps this goes along with increased precipitation and higher concentration of landslide events (Soldati et al 2004). A lake level reconstruction for the Western Alps supports this finding with evidence for a hydrologically distinctly wetter period between 2750 and 2350 cal. BP (Magny 2004). Moreover, enhanced flood intensities are 
documented by flood layers in lake sediments from the Southern Alps between 4200 and 2400 cal. BP with wettest conditions from 2700-2400 cal. BP (Vannière et al 2013; Wirth et al 2013). This timing agrees with a distinct minimum in total solar irradiance around $2700 \mathrm{cal}$. BP (Steinhilber et al 2009) and can be explained by an exceptional southward shift of the Westerlies in response to a more negative state of the North Atlantic Oscillation (NAO) responsible for colder climatic conditions in the Alps and intense flooding especially for the Southern Alps (Wirth et al 2013). Hydroclimatic evidences not only support the concentration of landslides during this time window but also provide heavy rainfall as a reasonable trigger for the Monte Peron Landslide at 2900 cal. BP according to our chronology. Thus, the Masiere di Vedana would fall into a Late Holocene period with frequent mass wasting events just like the sedimentologically evidenced mass wasting event in the catchment area of the Cordevole River dated in the sediments of Lago di Vedana to $2580 \mathrm{cal}$. BP. Heavy rainfall as a trigger for the Monte Peron Landslide would be difficult to accept for the timing obtained by exposure dating $\left(2^{\text {nd }}\right.$ century $\left.\mathrm{AD}\right)$, which coincides with the warm and dry Roman Climate Optimum. For this interpretation, a major earthquake has to be assumed as potential trigger as suggested by Rossato et al (2020).

Aside from landslides being triggered by hydroclimatic conditions, also past human activities have been modified by climatic conditions. Therefore, on the one hand it is pertinent to assume that the demise of the Certosa in the $18^{\text {th }}$ and $19^{\text {th }}$ century may have also been influenced by less favorable climatic conditions for agriculture as they prevailed during the Little Ice Age. On the other hand, the increase of monastic activities during the $12^{\text {th }}$ to $15^{\text {th }}$ century may have been related to more favorable climatic conditions during the Medieval Climatic Anomaly.

\section{Conclusions}

Past landslides contain information about their hydrological and geological context and assist to better control and predict future behaviors of instable slopes (Dapples et al 2002). As mass wasting events in alpine valleys often are accompanied by landslide-dammed lakes, their lacustrine sediments provide ideal opportunities for the study of past environmental conditions. Combining limnogeological and geochemical techniques for the study of these sediments, like it has been achieved in the course of this study, allows a reliable reconstruction of landscape evolution.

A prominent result of our radiocarbon-dated sediment stratigraphy from Lago di Vedana is the new date for the timing of the Monte Peron Landslide in the Dolomites (NE Italy). With 2900 cal. BP, this timing contradicts previous age estimations such as the much older and geomorphologically constrained Late Pleistocene age of 19,600-18,200 cal. BP (Pellegrini et al 2006) and the very young cosmogenic exposure ${ }^{36} \mathrm{Cl}$ age of $1.9 \mathrm{ka}$ (Rossato et al 2020). However, our new timing matches well with the occurrence maximum of landslides in the Dolomites at the transition from the Subboreal to the Subatlantic between 4200 and $2400 \mathrm{cal}$. BP (Soldati et al 2004), a period of lower temperatures and heavy rainfall (Haas et al 1998; Wirth et al 2013). An additional, yet unknown, mass wasting event in the catchment area of the Cordevole River is supportive of this interpretation. This formerly undetected landslide was recognized in the sediment record of Lago di Vedana at $2580 \mathrm{cal}$. BP by a distinct layer of allochthonous organic and minerogenic detritus. Such a horizon is comparable to event layers reported from the Pescosta Paleolake (Corvara in Badia, Dolomites), which were firmly correlated to known Early Holocene landslides (Borgatti et al 2007).

Monte Peron Landslide, the second largest rock avalanche in the Dolomites, impounded the Cordevole River and created a landslide-dammed lake like many other regional landslides (Borgatti et al 2007; Giordano 2015; Pellegrini et al 2006; Rossato et al 2020; Soldati et al 2004). During this stage the much larger predecessor of Lago di Vedana recorded fine-grained minerogenic deposits. The influence of the Cordevole River disappeared around $\mathrm{AD} 1300$ and minerogenic deposits were replaced by organic and carbonaceous sediments of now endorheic Lago di Vedana. In consequence, the valley of Rio Ramon received no more water from the Cordevole River, the groundwater level was lowered, flooding of Torbe terminated and additional areas for agriculture were created. For these reasons an artificial opening of the valley blocked by landslide debris at Ponte di Mas is 
postulated. However, this needs to be further investigated by historians and archaeologists to clarify whether humans opened this blockage or the gorge was eventually created as the result of natural erosion.

Different information is provided by first organic sediment components of Lago di Vedana starting around AD 1150, when human land use was intensified with the foundation of the Ospizio di San Marco di Vedana. This caused soil erosion and a trend towards lake eutrophication with anoxia in bottom waters. Around AD 1300 this first eutrophication period ended, when the lake changed from an open to an endorheic lacustrine system. Since then, carbonates have gained importance over clastic deposits with calcium being introduced through karst aquifers from the immediate catchment area, a process that was absent or overprinted by minerogenic fluvial deposits before. During this period anoxia decreased in importance, perhaps as a result of oxygen being supplied via subaquatic wells. With the foundation of the monastery Certosa di Vedana, lacustrine organic productivity intensified again for more than two centuries. Most likely, this is related to deforestation and land-use change by the Carthusian monks as documented by an increase in non-arboreal pollen as well as of Anthropogenic Pollen Indicators (Fig. 6). During the $18^{\text {th }}$ and $19^{\text {th }}$ centuries, less organic matter was deposited, which coincides with the climax of the Little Ice Age but also with the monastery closing operations for ca. 110 years. In AD 1882 the Certosa was re-established and human influences increased once again. The youngest decades since AD 1950 are characterized in the lacustrine record by a development towards less eutrophic conditions, a process related to conversational measures. - Future investigations of this fascinating site should be fostered, including investigations of diatoms and higher resolution pollen studies with the attempt of extending analyses to basal minerogenic sediments. It would also be beneficial to intensify regional explorations of human influence through collaboration with historians and archaeologists.

Hydroclimatic extremes are gaining importance as global warming accelerates, especially in Alpine regions that are sensitive to changes in precipitation. Moreover, paleo-studies document that landslides in mountainous regions became more frequent under heavy rainfall regimes (cf., Borgatti and Soldati 2010). Thus, the predicted increase of rainfall intensities will be capable of destabilizing rocks in the mountains and serve as triggers for landslides, such as evidenced for historic Alleghe and modern Val Pola landslides in the Dolomites (Crosta et al 2004; Rossato et al 2018).

With this study we document that the Monte Peron Landslide was active during a period with low total solar irradiance, negative NAO and a corresponding southward shift of the Westerlies creating more precipitation for the Southern Alps (cf., Wirth et al 2013). Comparable scenarios might occur in consequence of global warming with predicted intensified precipitation adding to the already existing predisposition of the Dolomites to landslide activities.

\section{Availability of data and material}

Supplementary material to this article is available online. Additionally, the multiproxy dataset of the lacustrine sediment record from Lago di Vedana will be made accessible via the PANGAEA data archiving and publication system at https://doi.pangaea.de/10.1594/PANGAEA.xxxxxx.

\section{Acknowledgements}

We thank Clemens Stamm and Rafael Stiens for subsampling, sample preparation and analyses in the GEOPOLAR lab (University of Bremen). Thanks are extended to Michele de Zanet and Siria Biagioni (University of Göttingen) for organizing the permits to enter the Lago di Vedana area, for providing historical information of the study region and for logistical support while coring the lake. 


\section{References}

Aitchison J (1982) The statistical analysis of compositional data. Journal of the Royal Statistical Society. Series B: Statistical Methodology 44:139-177,

Andrich O, Cassol M, Crepaz A, Dall'Asta A, Decet F, Gnech R, Lasen C, Toffolet L (2001) Lago e torbe di Vedana: Programma comunitario "LEADER II" GAL2 - Prealpi e Dolomiti Bellunesi e Feltrine. pp 1-22,

Bacchetti F, Selle M (1985) Certosa di Vedana. Tipografia Piave, Sospirolo, p 159,

Barla G, Paronuzzi P (2013) The 1963 Vajont Landslide: 50th Anniversary. Rock Mechanics and Rock Engineering 46:1267-1270 https://doi.org/10.1007/s00603-013-0483-7

Behre K-E (1981) The interpretation of anthropogenic indicators in pollen diagrams. Pollen et Spores 23:225-245,

Blaauw M, Christen JA, Aquino Lopez MA (2021) rbacon: Age-Depth Modelling using Bayesian Statistics. R package version 2.5.1. ed, https://CRAN.R-project.org/package=rbacon

Blott SJ, Pye K (2001) GRADISTAT: a grain size distribution and statistics package for the analysis of unconsolidated sediments. Earth Surface Processes and Landforms 26:1237-1248 https://doi.org/10.1002/esp.261

Borgatti L, Ravazzi C, Donegana M, Corsini A, Marchetti M, Soldati M (2007) A lacustrine record of early Holocene watershed events and vegetation history, Corvara in Badia, Dolomites (Italy). Journal of Quaternary Science 22:173-189 https://doi.org/10.1002/jqs.1039

Borgatti L, Soldati M (2010) Landslides as a geomorphological proxy for climate change: A record from the Dolomites (northern Italy). Geomorphology 120:56-64 https://doi.org/10.1016/i.geomorph.2009.09.015

Bronk Ramsey C (2009) Bayesian analysis of radiocarbon dates. Radiocarbon 51:337-360,

Cariali F (1998) L'impianto monastico di S. Marco di Vedana: dal 'modello' del secolo XV al secolo XIX. in: Marin F, Magoga Da Via LS (eds), La Certosa di Vedana: Storia, cultura e arte in un ambiente delle Prealpi bellunesi. Olschki, Firenze, pp 101-116,

Crosta GB, Chen H, Lee CF (2004) Replay of the 1987 Val Pola Landslide, Italian Alps. Geomorphology 60:127-146 https://doi.org/10.1016/j.geomorph.2003.07.015

Croudace IW, Löwemark L, Tjallingii R, Zolitschka B (2019) Current perspectives on the capabilities of high resolution XRF core scanners. Quatern Int 514:5-15 https://doi.org/10.1016/j.quaint.2019.04.002

Croudace IW, Rindby A, Rothwell RG (2006) ITRAX: description and evaluation of a new multifunction X-ray core scanner. in: Rothwell RG (ed), New techniques in sediment core analysis. The Geological Society of London Special Publications, London, pp 51-63,

Croudace IW, Rothwell RG (2015) Future Developments and Innovations in High-Resolution Core Scanning. Dev Paleoenviron Res 17:627-647 https://doi.org/10.1007/978-94-017-9849-5 27

Dai Pra G, Giardini M (2001) Cenni geomorfologici, litologia e analisi pollinica dei sedimenti olocenici dell'antico lago di Agordo (Dolomiti Orientali). Italian Journal of Quaternary Sciences 14:187198 ,

Dapples F, Lotter AF, van Leeuwen JFN, van der Knaap WO, Dimitriadis S, Oswald D (2002) Paleolimnological evidence for increased landslide activity due to forest clearing and land-use since 3600 cal BP in the western Swiss Alps. Journal of Paleolimnology 27:239-248,

Dikau R, Schrott L (1999) The temporal stability and activity of landslides in Europe with respect to climatic change (TESLEC): main objectives and results. Geomorphology 30:1-12 https://doi.org/https://doi.org/10.1016/S0169-555X(99)00040-9

Folk RL, Ward WC (1957) Brazos river bar: a study in the significance of grain size parameters. Journal of Sedimentary Petrology 27:3-26,

Giordano D (2015) Le Masiere di Vedana aspetti geologici. La frana del Monte Peron. in: Pro Loco Monti del Sole di Sospirolo a cura di Alba Barattin e Francesco Bacchetti (ed), L'Oro di Cornia la natura e gli uomini nel paesaggio delle Masiere di Vedana. Topografia Piave, Belluno, pp 29-116, 
Govi M (1989) The 1987 landslide on Mount Zandila in the Valtellina, Northern Italy. Landslide News 3:1-3,

Haas JN, Richoz I, Tinner W, Wick L (1998) Synchronous Holocene climatic oscillations recorded on the Swiss Plateau and at timberline in the Alps. The Holocene 8:301-309,

Hajdas I, Sojc U, Ivy-Ochs S, Akçar N, Deline P (2021) Radiocarbon Dating for the Reconstruction of the 1717 CE Triolet Rock Avalanche in the Mont Blanc Massif, Italy. Frontiers in Earth Science 8 https://doi.org/10.3389/feart.2020.580293

Huggel C, Clague JJ, Korup O (2012) Is climate change responsible for changing landslide activity in high mountains? Earth Surface Processes and Landforms 37:77-91 https://doi.org/10.1002/esp.2223

Jenny J-P, Normandeau A, Francus P, Taranu ZE, Gregory-Eaves I, Lapointe F, Jautzy J, Ojala AEK, Dorioz J-M, Schimmelmann A, Zolitschka B (2016) Urban point sources of nutrients were the leading cause for the historical spread of hypoxia across European lakes. Proceedings of the National Academy of Sciences 113:12655-12660 https://doi.org/10.1073/pnas.1605480113

Liu X, Colman SM, Brown ET, Minor EC, Li H (2013) Estimation of carbonate, total organic carbon, and biogenic silica content by FTIR and XRF techniques in lacustrine sediments. Journal of Paleolimnology 50:387-398 https://doi.org/10.1007/s10933-013-9733-7

Magny M (2004) Holocene climate variability as reflected by mid-European lake-level fluctuations and its probable impact on prehistoric human settlements. Quatern Int 113:65-79 https://doi.org/10.1016/s1040-6182(03)00080-6

Martin-Puertas C, Tjallingii R, Bloemsma M, Brauer A (2017) Varved sediment responses to early Holocene climate and environmental changes in Lake Meerfelder Maar (Germany) obtained from multivariate analyses of micro X-ray fluorescence core scanning data. Journal of Quaternary Science 32:427-436 https://doi.org/10.1002/jgs.2935

Mercuri AM, Bandini Mazzanti M, Florenzano A, Montecchi MC, Rattighieri E, Torri P (2013) Anthropogenic pollen indicators (API) from archaeological sites as local evidence of humaninduced environments in the Italian peninsula. Annali di Botanica (Roma) 3:143-153 https://doi.org/10.4462/annbotrm-10316

Meyers PA, Teranes JL (2001) Sediment Organic Matter. in: Last WM, Smol JP (eds), Tracking Environmental Change Using Lake Sediments. Volume 2: Physical and Geochemical Methods. Kluwer Academic Publishers, Dordrecht, pp 239-269,

More KS, Wolkersdorfer C (2019) An analogue Toma Hill formation model for the Tyrolian Fernpass rockslide. Landslides 16:1855-1870 https://doi.org/10.1007/s10346-019-01211-w

Müller PJ, Schneider R (1993) An automated leaching method for the determination of opal in sediments and particulate matter. Deep Sea Research Part I: Oceanographic Research Papers 40:425-444,

Nesje A, Søgnen K, Elgersma A, Dahl SO (1987) A Piston Corer for Lake Sediments. Norsk Geografisk Tidsskrift - Norwegian Journal of Geography 41:123-125 https://doi.org/https://doi.org/10.1080/00291958708621986

Nowaczyk NR (2001) Logging of magnetic susceptibility. in: Last WM, Smol JP (eds), Tracking environmental changes using lake sediments. Volume 1: Basin analysis, coring, and chronological techniques. Kluwer Academic Publishers, Dordrecht, The Netherlands, pp 155-170,

Pellegrini GB, Surian N, Albanese D (2006) Landslide activity in response to alpine deglaciation - the case of the Belluno Prealps. Geografia Fisica e Dinamica Quaternaria 29:185-196,

Petley D (2012) Global patterns of loss of life from landslides. Geology 40:927-930,

Pignatti E, Pignatti S (2014) Plant Life of the Dolomites. Springer, Berlin, Heidelberg

Polgar IS, Zolitschka B, Behling H (subm.) Human Impact on Vegetation History of the last millennium reconstructed from sediments of Lago di Vedana, Northern Italy. NN,

Reimer PJ, Austin WEN, Bard E, Bayliss A, Blackwell PG, Bronk Ramsey C, Butzin M, Cheng H, Edwards RL, Friedrich M, Grootes PM, Guilderson TP, Hajdas I, Heaton TJ, Hogg AG, Hughen KA, Kromer B, Manning SW, Muscheler R, Palmer JG, Pearson C, van der Plicht J, Reimer RW, Richards DA, Scott EM, Southon JR, Turney CSM, Wacker L, Adolphi F, Büntgen U, Capano M, Fahrni SM, Fogtmann- 
Schulz A, Friedrich R, Köhler P, Kudsk S, Miyake F, Olsen J, Reinig F, Sakamoto M, Sookdeo A, Talamo S (2020) The IntCal20 Northern Hemisphere Radiocarbon Age Calibration Curve (0-55 cal kBP). Radiocarbon 62:725-757 https://doi.org/10.1017/rdc.2020.41

Rossato S, Ivy-Ochs S, Martin S, Viganò A, Vockenhuber C, Rigo M, Monegato G, De Zorzi M, Surian N, Campedel P, Mozzi P (2020) Timing, drivers and impacts of the historic Masiere di Vedana rock avalanche (Belluno Dolomites, NE Italy). Natural Hazards and Earth System Sciences 20:21572174 https://doi.org/10.5194/nhess-20-2157-2020

Rossato S, Martin S, Ivy-Ochs S, Viganò A, Vockenhuber C, Rigo M, Surian N, Mozzi P (2018) Post LGM catastrophic landslides in the Dolomites: when, where and why. Alpine and Mediterranean Quaternary, Abstracts (AIQA 13-14.06.2018, Florence) AIQA 13-14.06.2018, Florence:239-242,

Rothwell RG (1989) The Smear Slide Method - An Optical Identification Guide. Springer, Dordrecht https://doi.org/10.1007/978-94-009-1133-8 2

Schreg R (2020) Human Impact on Hydrology. in: Chiarenza N, Haug A, Müller U (eds), The Power of Urban Water. De Gruyter, pp 249-264 https://doi.org/10.1515/9783110677065

Soldati M, Borgatti L, Cavallin A, De Amicis M, Frigerio S, Giardino M, Mortara G, Pellegrini GB, Ravazzi C, Surian N, Tellini C, Zanchi A (2006) Geomorphological Evolution of Slopes and Climate Changes in Northern Italy during the Late Quaternary: Spatial and temporal distribution of landslides and landscape sensitivity implications. Geografia Fisica e Dinamica Quaternaria 29:165-183,

Soldati M, Corsini A, Pasuto A (2004) Landslides and climate change in the Italian Dolomites since the Late glacial. Catena 55:141-161 https://doi.org/10.1016/s0341-8162(03)00113-9

Steinhilber F, Beer J, Fröhlich C (2009) Total solar irradiance during the Holocene. Geophys Res Lett 36 https://doi.org/10.1029/2009gl040142

Strouth A, McDougall S (2021) Historical Landslide Fatalities in British Columbia, Canada: Trends and Implications for Risk Management. Frontiers in Earth Science 9

https://doi.org/10.3389/feart.2021.606854

Tjallingii R, Röhl U, Kölling M, Bickert T (2007) Influence of the water content on X-ray fluorescence core-scanning measurements in soft marine sediments. Geochemistry, Geophysics, Geosystems 8:1-12 https://doi.org/doi:10.1029/2006GC001393

Vannière B, Magny M, Joannin S, Simonneau A, Wirth SB, Hamann Y, Chapron E, Gilli A, Desmet M, Anselmetti FS (2013) Orbital changes, variation in solar activity and increased anthropogenic activities: controls on the Holocene flood frequency in the Lake Ledro area, Northern Italy. Clim Past 9:1193-1209 https://doi.org/10.5194/cp-9-1193-2013

Weltje G, Bloemsma M, Tjallingii R, Heslop D, Röhl U, Croudace I (2015) Prediction of Geochemical Composition from XRF Core Scanner Data: A New Multivariate Approach Including Automatic Selection of Calibration Samples and Quantification of Uncertainties. in: Croudace I, Rothwell R (eds), Micro-XRF Studies of Sediment Cores. Springer, Dordrecht, pp 507-534 https://doi.org/10.1007/978-94-017-9849-5 21

Weltje GJ, Tjallingii R (2008) Calibration of XRF core scanners for quantitative geochemical logging of sediment cores: Theory and application. Earth and Planetary Science Letters 274:423-438 https://doi.org/10.1016/j.epsl.2008.07.054

Wirth SB, Glur L, Gilli A, Anselmetti FS (2013) Holocene flood frequency across the Central Alps solar forcing and evidence for variations in North Atlantic atmospheric circulation. Quaternary Sci Rev 80:112-128 https://doi.org/10.1016/j.quascirev.2013.09.002

Woodward CA, Gadd PS (2019) The potential power and pitfalls of using the X-ray fluorescence molybdenum incoherent: Coherent scattering ratio as a proxy for sediment organic content. Quatern Int 514:30-43 https://doi.org/10.1016/i.quaint.2018.11.031 


\section{Figures}

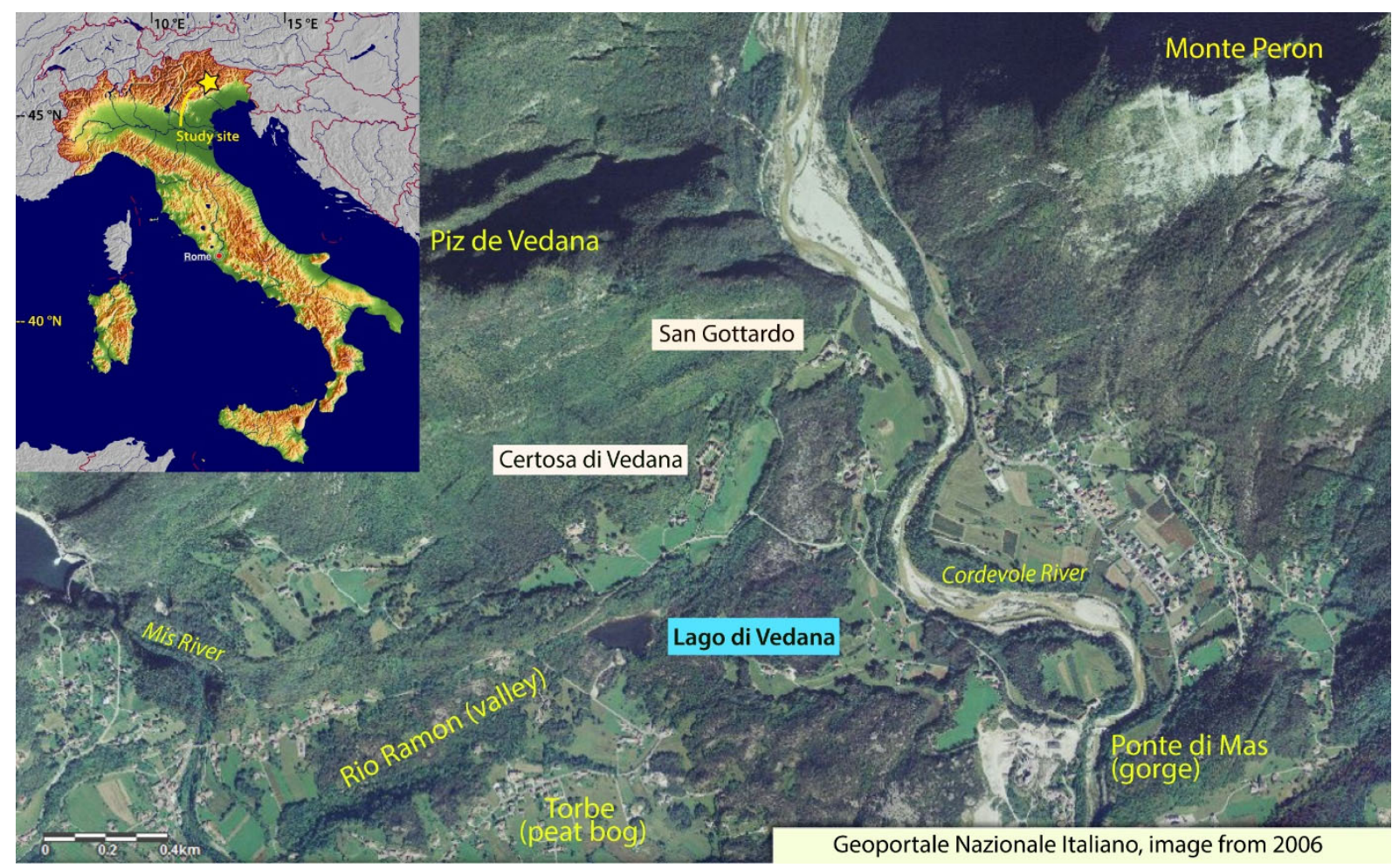

Fig. 1 Aerial photography (http://www.pcn.minambiente.it) of the study area with sites mentioned in the text. Shaded topographic map of Italy (http://www.ginkgomaps.com) shows the location of Lago di Vedana in NE Italy (marked with a yellow star in the insert) 


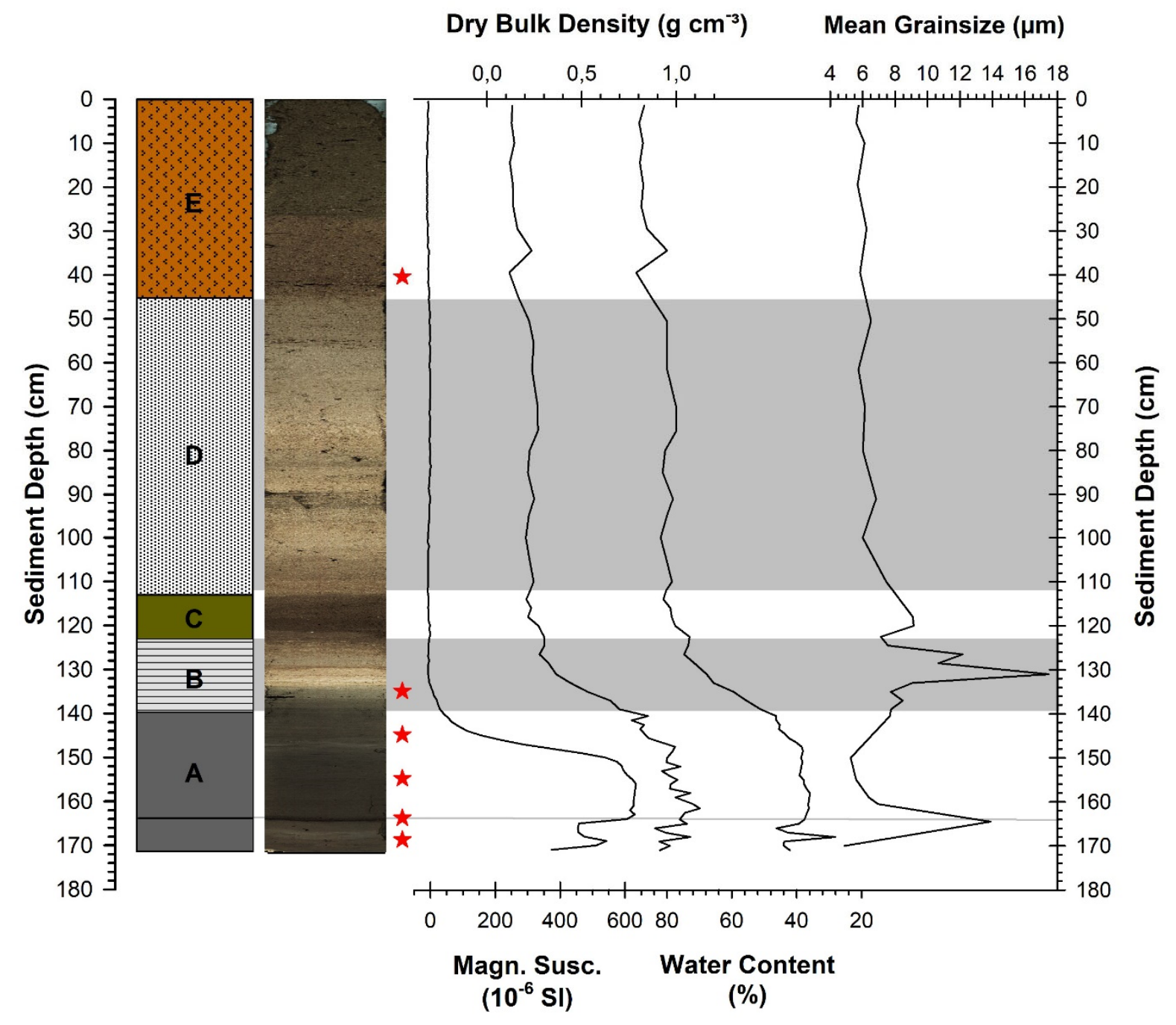

Fig. 2 Lithology with physical and sedimentological parameters. From left to right: Lithology with lithozones A to E: (A) Gray minerogenic mud with a thin black layer of sandy silt rich in organic matter at $164 \mathrm{~cm}$; (B) Olive to yellowish gray faintly laminated, diatomaceous and carbonaceous mud; (C) Olive black organic mud; (D) Grayish olive to grayish yellow carbonaceous organic mud; (E) Gray to grayish yellow gas-rich organic mud; Photography of the split core; Position of samples for radiocarbon dating marked by red stars; Profiles of magnetic susceptibility (Magn. Susc.), dry bulk density, water content (with inversed x-axis!) and mean grainsize. Lithozones B and D are shaded in gray 


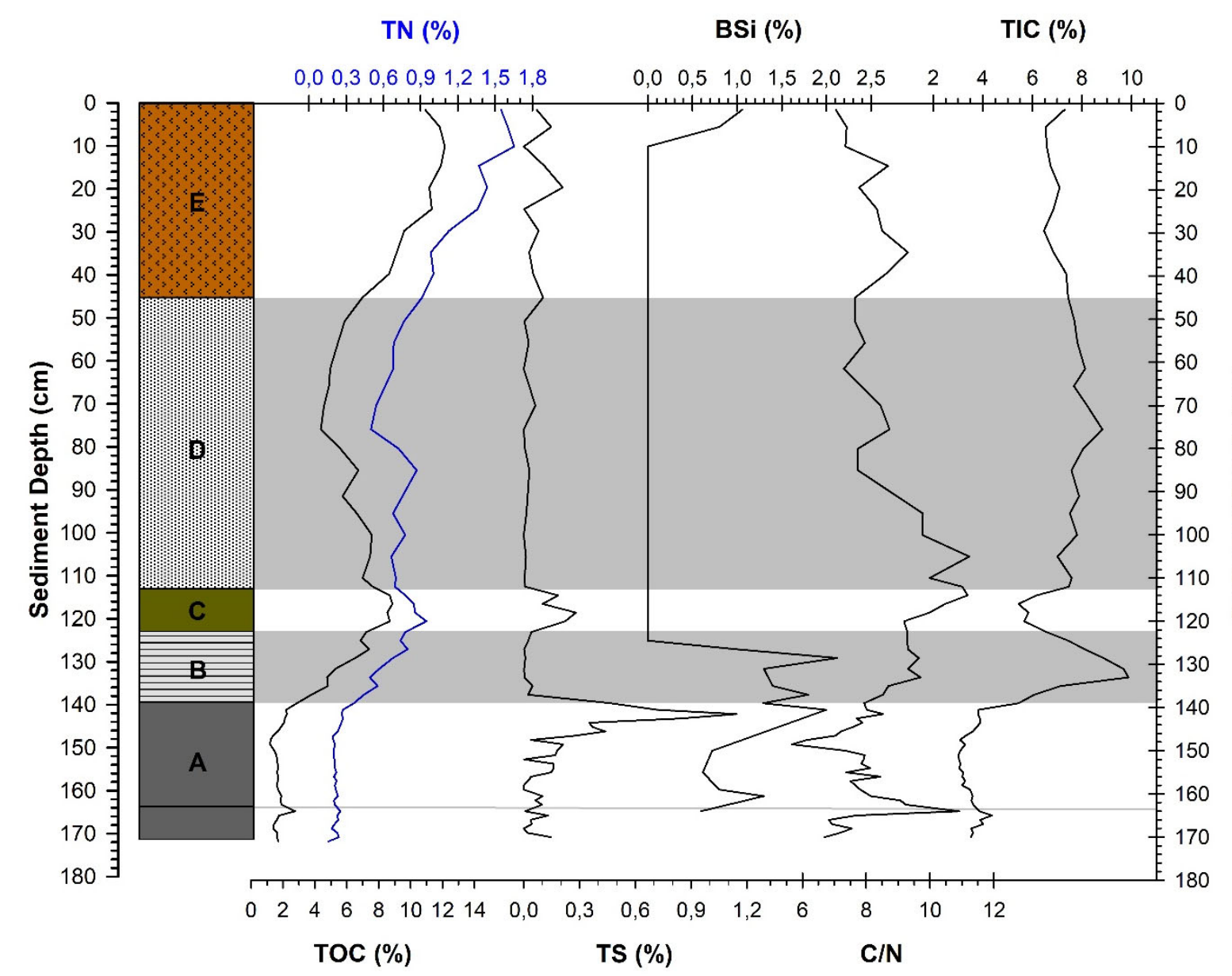

Fig. 3 Lithology with bulk geochemical data of total organic carbon (TOC), total nitrogen (TN; values are only shown for information but not discussed in the text as they correlate highly $(\mathrm{r}=0.97)$ with TOC), total sulphur (TS), biogenic silica (BSi), carbon-to-nitrogen ratio (C/N) and total inorganic carbon (TIC). Lithozones B and D are shaded in gray 


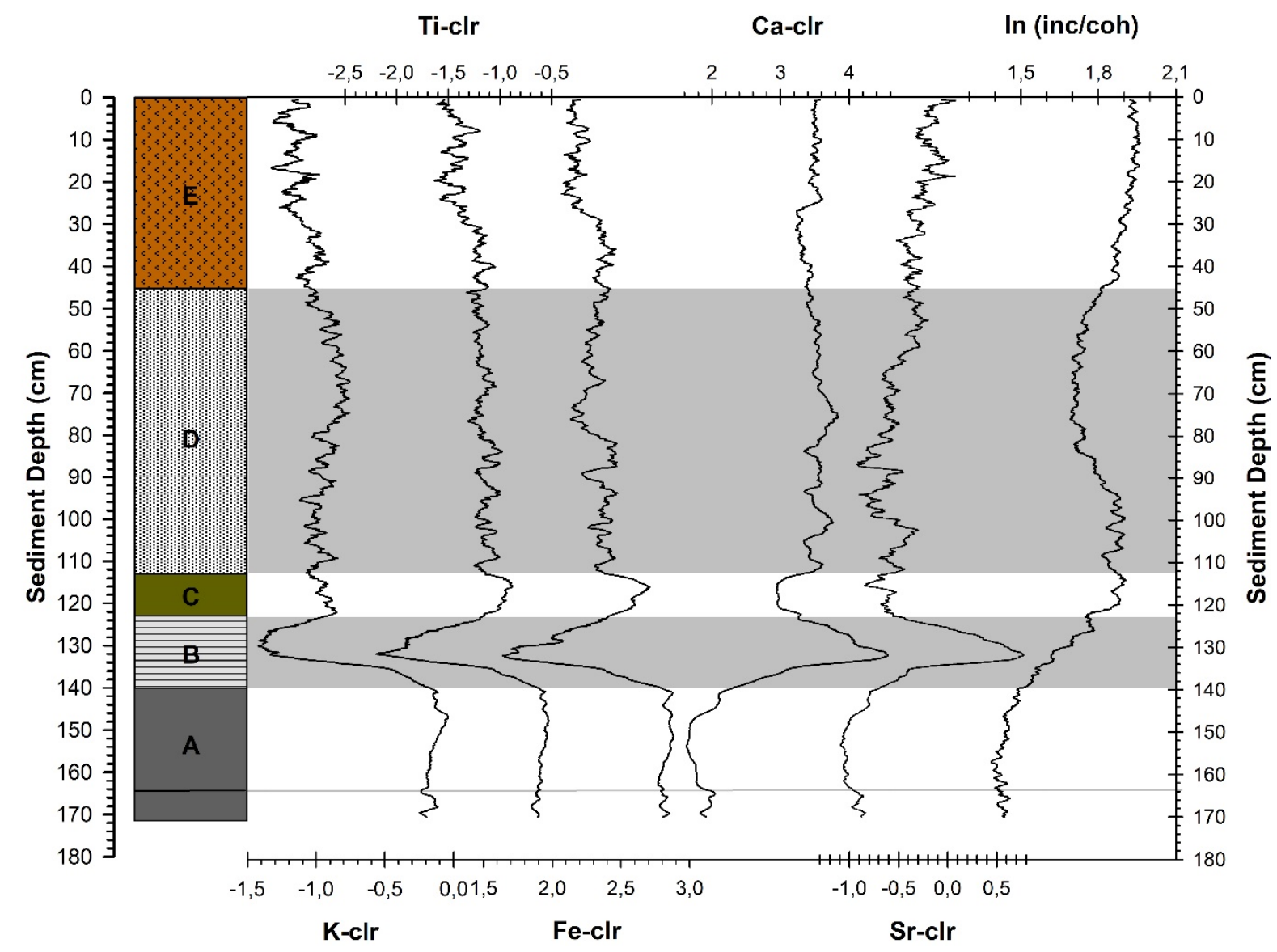

Fig. 4 Lithology with XRF core scanning data for the selected elements of potassium (K), titanium (Ti), iron $(\mathrm{Fe})$, calcium $(\mathrm{Ca})$, strontium $(\mathrm{Sr})$ and the ratio of incoherent-to-coherent radiation as $\ln$ (inc/coh). All elemental data are transformed to centered log ratios (clr). Lithozones B and D are shaded in gray 

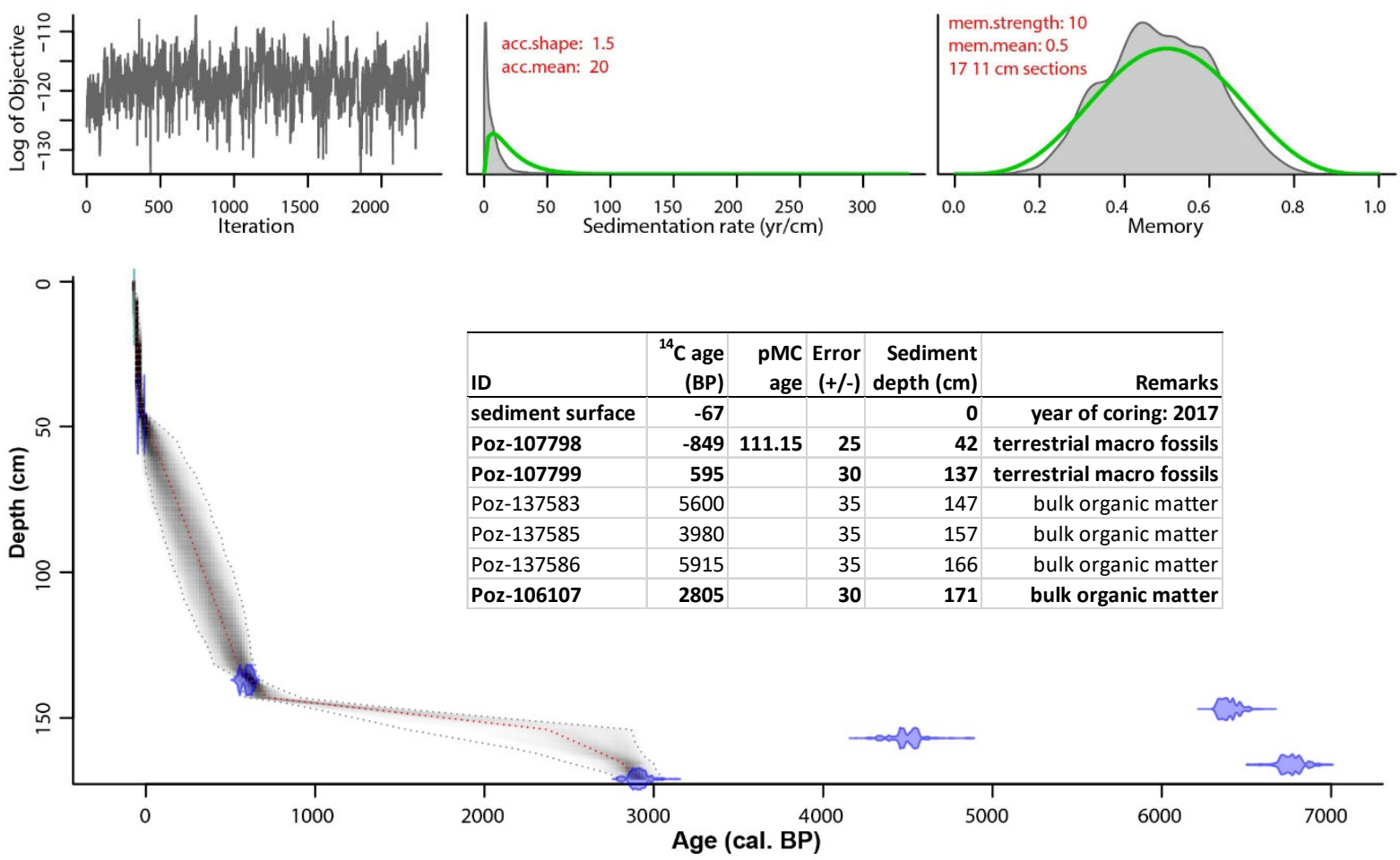

Fig. 5 Age-depth relationship modelled with "rbacon" based on radiocarbon dates and the sediment surface. All information related to radiocarbon dates is provided by the inserted table (pMC: percent modern carbon). Ages used for age-depth modelling are shown in bold 


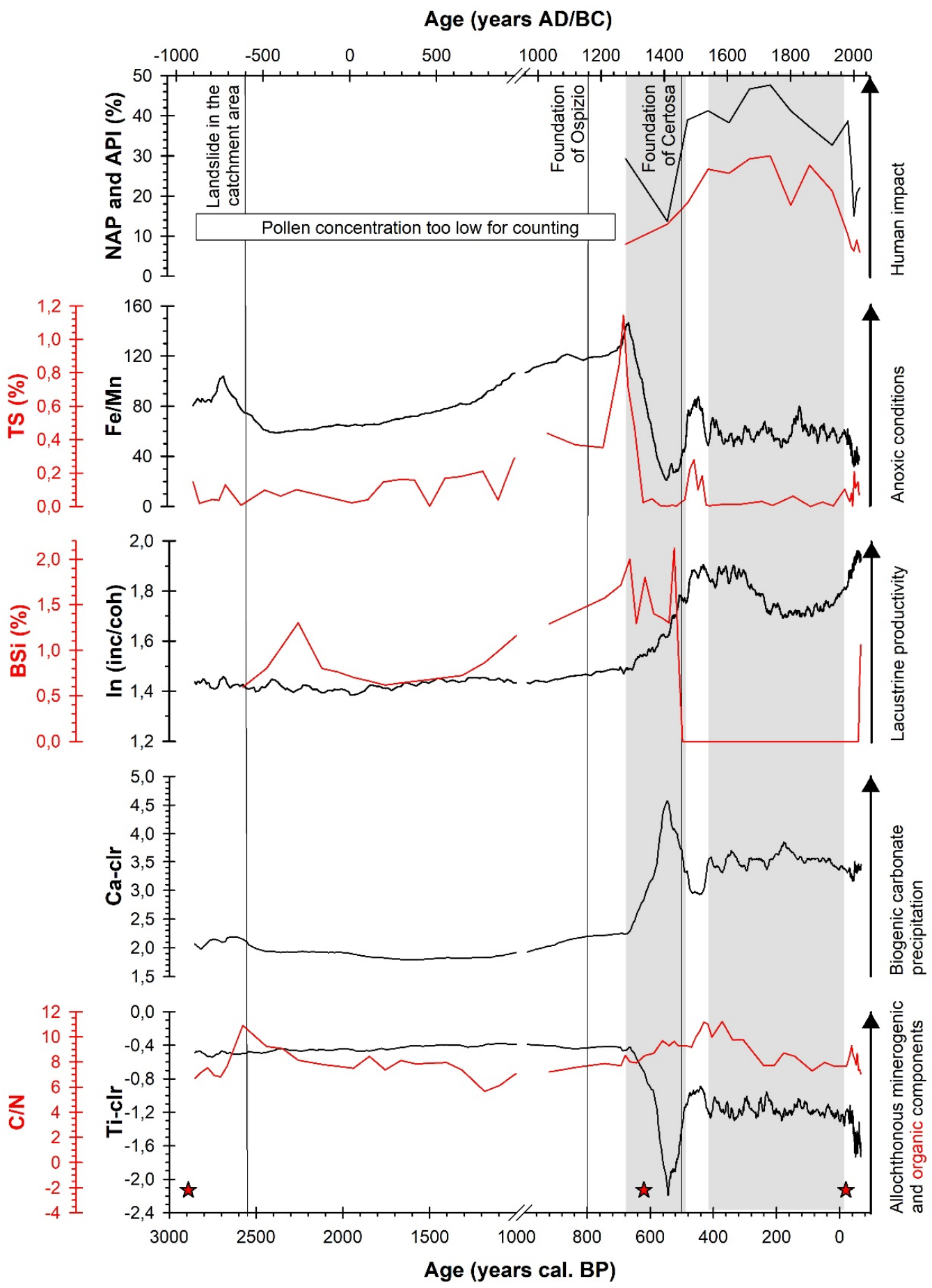

Fig. 6 Interpretation of analyzed environmental parameters vs. time (please observe the change in scale for the $x$ axis at 1000 cal. BP). From top to bottom: non-arboreal pollen (NAP) and primary anthropogenic pollen indicators (API) consisting of chestnut (Castanea), walnut (Juglans), olive tree (Olea), hemp/hops (Cannabis/Humulus), grains (cerealia), vine (Vitis), corn (Zea mays) und buckwheat (Fagopyrum) according to Polgar et al (subm) representing human impact; total sulphur (TS) and iron-to-manganese ratio (Fe/Mn) representing anoxic conditions; biogenic silica $(\mathrm{BSi})$ and the ratio of incoherent-to-coherent radiation (ln inc/coh) representing lacustrine productivity; centered log ratio-transformed calcium (Ca-clr) representing biogenic carbonate precipitation; and carbon-to nitrogen ratio $(\mathrm{C} / \mathrm{N})$ and centered log ratio-transformed titanium (Ti-clr) representing allochthonous organic and minerogenic sediment components, respectively. Position of radiocarbon dates are indicated as red stars. Vertical lines mark events in the catchment area (as labeled). Lithozones B and D are shaded in gray 


\section{Supplementary figure}

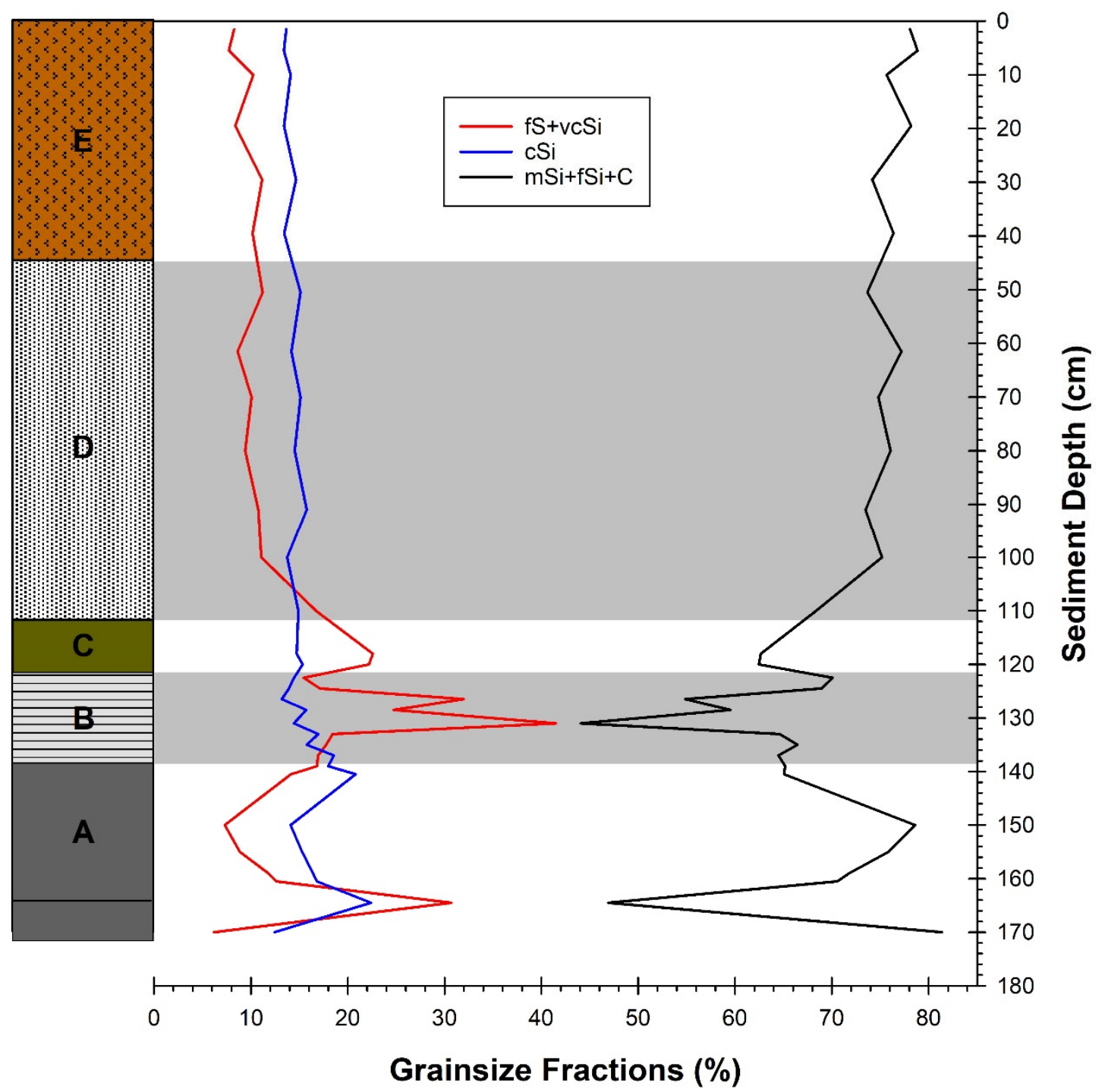

Fig. A1 Lithology displaying the grainsize fractions fine sand and very coarse silt (fS+vcSi) as a red line, coarse silt ( $\mathrm{cSi})$ as a blue line and medium silt, fine silt and clay $(\mathrm{mSi}+\mathrm{fSi}+\mathrm{C})$ as a black line. Lithozones $\mathrm{B}$ and $\mathrm{D}$ are shaded in gray 